\title{
Acknowledgments
}

$\mathrm{T}$ he questions driving this book emerged outside of or against the university, through the reading groups, committee meetings, and actions associated with the University of California Student Occupation Movement, Occupy Oakland, and associated anarchist, leftcommunist, feminist, queer, and antiracist organizing in the Bay Area from 2009 through 2014. I am so grateful for these communities, alongside the wider extra-academic political formations that have sustained and challenged me in the subsequent years spent on the East Coast, in New Haven, Philadelphia, and Brooklyn.

At the same time, this book was made possible through sustained institutional support on many fronts. In the Department of English at the University of California, Berkeley, I owe special thanks to my formidable advisors Charles Altieri, Dan Blanton, and Lyn Hejinian. I am particularly appreciative of this group for their continuous goodwill and encouragement when I changed the focus of my research midstream, from aesthetic theory to radical feminism. At Berkeley, I am also thankful for a number of excellent teachers and mentors in the English Department and beyond, including Kathleen Donegan, Eric Falci, Cecil Giscombe, Kevis Goodman, Celeste Langan, Colleen Lye, Maura Nolan, and Linda Williams. I want to send extra gratitude to Dan Blanton for his generous and devastatingly smart readings of my writing well after graduation. Lyn Hejinian was an invaluable source of inspiration for political, and especially feminist, organizing in the academy. I feel especially lucky to have as classmates the marvelous Sookyoung Lee, Lili Loofbourow, Batya Ungar-Sargon, and Mia You. My dissertation 
work was supported by grants from the Summer Mellon Dissertation Seminar Fund, taught by Michael Lucey and the Chernin Program, then headed up by Maura Nolan, who was an outstanding mentor when I needed one the most.

In Berkeley and Oakland but extending outside the strict context of institutional affiliation, thank you and love to my housemates at Casa Milvia, Sarah Chihaya and Jessica Crewe, who shared conversation, writing, and late-night movie trivia that sustained me through graduate school. Thanks to Jessie Hock and Alex Dubilet, not least for their sunny, book-filled apartment as a rest stop. I owe so much to my weekly television buddy and teargas hand-holder Callie Maidof. More widely, gratitude and love to an Oakland crew including but not limited to Jasper Bernes, Matt Bonal, Shane Boyle, Chris Chen, Joshua Clover, Chris Nealon, Dan Nemser, Oki Sogumi, Juliana Spahr, and Wendy Trevino. Tim Kreiner deserves special mention and thanks for many years of support. Thanks too to Meredith Wallis, for California activist lawyering and East Coast friendship over the phone. Finally, thank you and appreciation to the ACLU lawyers who argued a class-action lawsuit against the city of Oakland and Alameda County for the mass arrests on January 28, 2012. That settlement paid for a summer of writing this book, though it meant a lot more than that to many different people.

In turning from California to Connecticut, I am first struck by my vast good fortune to have joined the English Department at Yale the same year as the indomitable Marta Figlerowicz, who has provided years of witty commentary, last-minute read-throughs, and solidarity in friendship. Sunny Xiang joined us the next year, along with Rasheed Tazudeen, to form the reconstituted Berkeley network of my dreams. During this time, Briallen Hopper has been a fount of kindness and grace, Greta LaFleur an indefatigable joy, and Eda Pepi my dearest coconspirator. Big thanks to Jill Jarvis, for friendship, dog-walking company, and generous readings of this work when the writing was in the weeds. Lucia Hulsether deserves special thanks for her support during late-stage editing meltdowns. I am most grateful for the existence of my New Haven therapist, Isha Vela, who helped me keep mind and body together over the course of several years. Amid the morass of hasty revisions, Brandon Proia was an excellent developmental editor, offering key suggestions for concision and clarity throughout. In the English Department, Joe Cleary, Wai Chee Dimock, Ben Glaser, Jacqueline Goldsby, Langdon Hammer, Cajetan Iheka, David Kastan, Naomi Levine, 
Katja Lindskog, Priyasha Mukhopadhyay, Stephanie Newell, Catherine Nicholson, Joe North, Anthony Reed, and Katie Trumpener offered academic and extracurricular support. Extra thanks to Caleb Smith, for his generous reading of drafts and direction amid bureaucratic tangles. In Women, Gender, and Sexuality Studies, I am thankful to have worked with two brilliant, supportive chairs, Inderpal Grewal and Margaret Homans, and for the queer comradeship of Serena Bassi, Igor De Souza, Robin Dembroff, Joe Fischel, and Evren Savci. Katie Lofton deserves a sentence of her own of enthusiastic thanks, for mentorship and much-needed encouragement. I am thankful to have worked as a Mellon Dissertation Workshop fellow, particularly alongside Doug Rogers, who has taught me much about what mentorship can look like in the best of circumstances. At Yale, this book has been supported by the grants from the Fund for Lesbian and Gay Studies (FLAGS) Research Award, A. Whitney Griswold Faculty Research Fund, and the Frederick W. Hilles Publication Fund.

This book benefited from a manuscript workshop, and I am so thankful to participants Ann Cvetkovich, Michael Denning, Inderpal Grewal, and Paul Saint-Amour for their generous reading and suggestions. Over the years, I have given a number of presentations from these materials and am particularly indebted to the brilliant Elizabeth Anker for a wonderful experience at the Law and Humanities Colloquium at the Cornell Law School. Thank you to the people at MODS: Twentieth-Century Graduate Reading Group at the University of Pennsylvania, especially Jed Esty and Paul Saint-Amour, for their warm welcome and good cheer while I was living in Philadelphia. I had a great time and conversation with Lori Cole and the Center for Comparative Modernism Working Group at New York University. Particular gratitude goes to Sara Crangle and Natalia Cecire, as my hosts and interlocutors at the Center for Modernist Studies, Sussex University. Thank you to Melissa Zeiger and the Department of English at Dartmouth University for their interest in the history of feminist bureaucracies. At Columbia University Press, I am particularly thankful to be working for the second time with such a smart and kind editor, Philip Leventhal, alongside the fantastic editors for the Modernist Latitudes Series, Jessica Berman and Paul Saint-Amour.

The driving intellectual force for good in my life comes from Gina Patnaik and Kelly Rich, whose ongoing conversations, writing retreats, and friendship is inestimable. In Philadelphia, special thanks to Eli Kim, who 
kept me going during a year of no schedule and remains a dear friend and cheerful recipient of too many dog selfies. In New York, I am grateful for the comradeship of Michelle O'Brien, who keeps me hopeful about the prospect of queer communism. Emma Heaney has scraped me off the floor, read the worst of bad drafts, and answered the phone in the middle of the night, alongside other life-sustaining acts of friendship. Thank you too to my Ferrante Letters cowriters and brilliant friends, Sarah Chihaya, Merve Emre, and Katherine Hill, who worked through many of these ideas in other venues and remain my go-to sites for writerly inspiration. Left Coast beloveds Shu Dar Yao and Melani Baker, alongside my dearest born-again Texan, Kristin Nolan, deserve special thanks for their enduring care and encouragement in sickness and in health. My parents, Steve and Carol Richards, have been very patient over too many years of my writing-induced anxiety, slow progress, and job-precarity grumpiness. On both coasts, I have relied on their love and support from West Texas. This book should rightfully be dedicated to my parents, but I am sure they will understand if I extend the umbrella of gratitude to include Dave Bush, the best of best brothers-in-law, close to my heart for more than a decade now, and, finally, to the person in my life who does too many admirable things to name but is most regularly a sustaining force of gravity when the world goes upside-down, my sister, Dawn Michelle Bush. 


\section{THE FURY ARCHIVES}


